\section{POLYPI IN THE HEART.}

\section{To the Editor of Trie Lancer.}

SrR,-As doubts have been, and are still entertained, of the truth of true polypi having been found attached to the internal surface of the theart, the following account of a post-mortem examination will not be uninteresting to the numerous readers of your Journal.

I had been for some time attending a lady labouring under chronic bronchitis, attended with the usual symptoms of that complaint, viz. dificult respiration, with a cough and expectoration of frothy muccus or mucopurulent matter, or what, perhaps, might with more propriety be called a morbid secretion of mucus, possessing the natural tenacity of healthy mucus, but thicker, and of a greenish hue, coming up in patches. The difficulty of breathing increased in the morning, and the expectoration more copious of course, from the accumulation of mucus during sleep. This complaint has not been inappropriately called by $D_{r}$. Badham, the winter cough, as it is always increased during the winter, and generally attacking those advanced in life, it usually terminates fatally in the fourth or fiftl winter. Plefore the fiood of light thrown on these diseases by Bichat's more particular description of the anatomy of the mucous membranes, it was, and is still called by many, hummal asthma. It lias also been confounded by Dr. Thomas, in his Practice of Phycic, with peripneumonia notha. These cursory observations are, no doubt, superfuous to some, but as this disease is yet but imperfectly understood by many, they are not wholly unnecessary. My patient had reached to the fifth season with this commlaint, and from the emaciation and increasced difficulty in breathing, it was easy to prognosticate that she would not get through this winter. On Thursday, December 14, not having seen her for a day or two, I was sent for, and found her sitting up as usual in her bed-room ; she complained that her appetite, which had been heretofore good, began to fail ; that her nights had been restless, her sleep being broken by the cough and expectoration. She therefore requested an opiate, which she had been occasionally in the labit of taking; I gave her a dose of Dover's powder, combined with squill, which she took early in the evening; and when her attendant left her at about one in the morning, she described herself as feeling comfortable. I was sent for in haste about eight o clock, and found her just dead. Although this disease usually terminates rather suddenly, yet as it appeared unusually so in this case, I requested a post-mortem examination, and on Sunday, December 17, accompanied by my intelligent friend and neighboil MIr. Perfect, we proceeded to the examination. On opening the thorax, we found the adhesions very considerable between the plenra pulmonalis and pleura costalis, so as to require much force in detaching the lungs from the chest and diaphragm. On opening the pericardium, there was an unusual quantity of effusion into that cavity, about five or six ounces. There was also a slight effusion into the cavity of the chest. Having remored the heart, on examining it, the aorta was foud somewhat increased in size, but there was no disease or ossification in it, or in the pulmonary artery. The heart itself was not enlarged, nor on opering the left auricle and ventricle were its parietes thickened. On slitting up the vena cava and right auricle and ventricle, a yollow fatty substance presented itself, beginning and attached by rather a broad basis in the internal surface of the right apendix auriculi, and becoming somewhat expanded, extending across the auricle into the ventricle, and terminating in two long peduncles, about two inches in length. It was pretty firmly attached in its whole course. On examining the lungs, the minute ramifications of the bronchiæ and air-cells contained morbil mucus; but there were no signs of infinmation or ulceration in the mucous mem. brane or substance of the lungs; no hepatization or obliteration in the air-cells. The material point in this case is evidently the polypus in the heart. Now the existence of these substances has been affirmed by Tul. pius, Malpighi, and Pechlinus, whilst Therltringius and others have denied that true polypi have ever been found in the heart, and believed that they were merely the 0. agulated fibrin of the blood formed in the moment of death, which substances Therlu. ringius called pseudo-polypi. In this opinion he has been followed by Mr. John Bell, who begins by supposing the question to be, whether blood sometimes coagulates, and forms polypi in enlarged hearts. Setting out with this idea, he argues on the improbability of blood coagulating in the heart itself during life, and becoming washed pure, and of a firm consistence, thus constituting polypi. In this I entirely agree with Mr. John Bell; but did he suppose that polypi in other parts are formed by coagulated blood? Surely not; then why in the heart? That coagulated blood, or even the fibrin of the blood, should form a substance in the heart at the moment of death, or in the slow approaches to it, is not improbable; and call such substances peudo-polypi, or what you will, they are quite distinet from true polypi, which are substances or. ganised and possessed of vitality, shootin: 
out from mucous surfaces. And there appears to me no reason whatever for supposing that polypi' in the heart are different from polypi in the nose, in the uterus, or in the rectum. The internal coat of the heart, like all membranes which come in contact with air or fuids, and attached to the internal parts of organs requircd to bo in motion, is a lubricating or mucous membrane. The fuency of Mr. John Bell's language, and the ingenuity of his reasoning, have deservedly made his works very generally read, and his opinions looked up to as authority. But when we consider that $\mathrm{NI}$. Bell denied the compressibility of the larger arteries by manual force, we must allow that he sometimes adopted opinions without mature deliberation. Whether the polypus in this case was the cause or consequence of the bronchial affection, is uncertain. I should rather say the latter. I am, however, quite satisfied, from the best of all evidence, that polypi are occasionally found shooting from the mucous membrane of the hèrt, as well as from other mucous surfaces. And I trust the publication of this case, and these observations, will lead to a more attentive examination of the heart in post-morten researches, when, I doubt not, the occasional existence of true polypi in it will be soon universally acknowleged. I am, Sir, yours,

W. Simpson.

Hammersmith,

Decenber, 20th, 1326.

\section{DR. B A R R $\mathbf{Y}$.}

\section{To the Editor of THE La NCET.}

$S_{I R,-} I_{N}$ your report of the proceedings of the Hunierian Society, (No. 173 of THE L.1Ncet,) a serious misstatement occurs with regard to Dr. Barry sheory of Absorption.

That gentleman is made to almit, (according to your Reporter,) that the exhausted cupping-glass prevents absorption in " the sume way" as Mrr. Ellerby's ferrule, viz. "by mechanical pressure applied round the poisoned round."

Dr. Barry's view of the subject is this, as expressed in his book, (p. 99,) in his Lectures, and at both the Hunterian and Iondon Nerlical societies: "That there are but two conditions indispensably necessary to enable any part of a living animal to absorb ; viz. 1st, i free conmunication between the part and the thoracic pumps. 2dly, A free application of atmospheric pressure to the absorbing point and the course of the communcation; consequently, that absorption must be rapid in direct proportion to the perfaction of these two conditions."
To prove this proposition, Dr. Barry removes the pressure of the atmosphere from a poisoned wound by means of an exhausted cupping-glass, and prevents absorption, although the communication is not cut off between the wound and the thorax.

Mr. Ellerby applies circular pressure round the poisoned wound, and cuts off the communication by obliterating the cavities of the veins and lymphatics, and prevents absorption, although the pressure of the atmosphere is not removed from the wound.

Dr. Barry claimed Mir. Ellerby's experiment as another denonstration of his (Dr. B's) proposition, and this itwas, no doubt, that led your Reporter into error.

Indeed, the application of pressure between a poisoned wound and the heart, is as old as that of the cupping-glass itself. Tide Experimental Researches (Barry's, p.77.)

Prilovacuuar.

London, Dec. 25, 1825.

\section{COLLEGE OF PHYSICIANS.}

\section{To the Editor of Tire Lancet.}

Sir,-Allow me to correct one important mistake, relative to the College of Physicians, in my last letter. Since its publication, $I$ am informed on good authority that the College possess no power whatever to prevent any medical graduate of any university, foreign or English, from practising as a physician in London.: if this, be the case, it ought to be generally known. I, for example, am a graduate of a universitg. When, however, it was proposed to me to take my Doctor's regree, maturer age and mature refection had convinced me of the dishonesty and immorulity of a feigned subscription on cath, to the thirty-nine articles of the Church of England. It seemed like a compromise of common honour, if the formula of subscription meant anything, to subscribe to fulsehood; and if it was a mere form, no honest man ought to give his countenance to a piece of gothic buffoonery which must tend essentidly to weaken in the minds of young persons the importance that ought to attach to an oath, or any serious assertion of opinion of any kind. Again, it is incompatible with the duty of a catholic in subscribe to any protestant test of any hind. Wven in cases where a mere form is the only thing pretended, we are not to compromise our character by flaying at lying for lucre of grain. At Cambridge a man can be a Bachelor of Physic without being a subscriber to the articles, having once been mairicalated ; and this is enough to be candidate for the Fellowship of Warwick Lane. But the same objection stands in the way of 